\title{
THE JURY TRIAL AND DEMOCRATIC VALUES: On The Twenty-First Century Incarnation of an Eighteenth Century Institution
}

\author{
Maxwell O. Chibundu ${ }^{1}$
}

In our contemporary culture, jury trial enjoys the kind of rarified reverence that only a handful of other institutions can lay claim to. Although occasionally subjected to criticism by contrarian scholars, the institution, whether in its grand or petit manifestation, its civil or criminal incarnation, is applauded as an exemplar of the virtues of democratic governance. Disagreement with outcomes in particular cases may be occasionally voiced, but such disagreements only burnish the legitimating norms of the institution. Charges of provincialism, lack of technical sophistication, or even sociological bias that, if leveled at other institutions might doom them, are viewed either as correctable minor flaws, or indeed as enhancing the popular grounding on which the legitimacy of the jury system rests. Directly put, the jury process is viewed and lauded as the application within the otherwise oligarchic judicial branch of those values of democratic rule that underpin the legitimacy of representative governance.

In the pages that follow, I ruminate on this widely acclaimed justification of the jury process. I explore whether democratic virtues, if embedded in the jury system, optimally validate it in a rule-based system of justice. Should the fact that the jury system may have functioned in earlier nondemocratic times as a means of checking the abuse of governmental power necessarily continue to lend it legitimacy in an era of popular democratic governance? What considerations ought to be factored in, both normatively and empirically, in determining the wholeheartedness with which the jury

\footnotetext{
${ }^{1}$ Professor, University of Maryland School of Law. This “ticket” to the 2007 University of Maryland Constitutional Law Schmooze is presented with appreciation to the students in my current Civil Procedure class whose questions and comments initiated the thoughts that are expressed below.
} 
should be embraced as an instance of democratic practice? The exploration proceeds along the following lines. First, I remark briefly on the historical grounding of the jury process. Next, I differentiate among the forms of the process with a view to elucidating the normative values that appear inherent in the various incarnations of the process. Thirdly, I discuss how these values enhance or are enhanced by the norms of democratic governance. And finally, I inquire into the continuing fit of the jury process and democratic governance.

\section{The Historical Grounding of the Jury Process}

It is commonplace to place the origins of the modern jury to Norman practice. To the extent that one assumes a Montesquieuan stance that privileges the hardened institutionalization of the formal separation of public powers over their overlapping functional use, then, this history may well be correct. In an essay about jury values and democratic rule, however, it would be remiss not to observe that the idea of using a college of decision-makers to dispose of a legal case has precedents in the Athenian Democracy and Roman Republic. The integral connection between "judging” and "ruling" of course dates even further back. It is probably not accidental that the first fully developed biblical account of the activities of the reputedly wise King Solomon was the description of his judicial resolution among two women of conflicting claims to the maternity of a newborn child. It is true that this activity takes place after he returns as an all-conquering King, and after worshipping and giving praise, but notably these latter events are cursorily depicted, while his role as a fact-gatherer and judge are presented in full bloom. 
These historical antecedents of the intertwining of judging and ruling having been noted, it is nonetheless the case that the jury trial, as practiced and venerated in the United States today has its direct precursor in English practice. This precedent is vitally important for at least two reasons. In the first place, the practice is enshrined in the foundational document of the Republic. Secondly, its scope and character are explicitly grounded in historical practice. The Seventh amendment of the Constitution thus confines the availability of the jury trial in civil cases to those situations in which they would have been available "at common law," and further restricts the re-examination of the "facts" found by a jury to common law practice. The Article III and sixth amendment's guarantees of jury proceedings in criminal cases are not anchored in textual historicism, but the nexus of those rights to due process requirements, and the central role that "tradition" plays in due process analysis effectively have rendered the interpretation of the right to jury trial even in criminal cases dependent on the exegesis of English history.

A primary lesson that many proponents of the jury trial draw from that history is that a group of ordinary Englishmen, relying on commonsense and an inbred aversion to tyranny, not infrequently employed their service on a jury to negate the best-laid plans of an overreaching monarch and her cabinet. Folklores of the jury in English Law thus often invoke instances in which the jury refused to convict in pseudo-criminal prosecutions (particularly in "sedition” cases), or returned verdicts of non-liability in politically charged defamation actions. In these cases, the jury, acting as the conscience of the community, and secure in the protection afforded by numbers and the requirement 
of unanimity, effectively checked governmental power; or at least its manifestations in particular cases.

Such illustrious English pedigree often is corroborated by pointing to nineteenth century examples in American history where ordinary citizens acting through the jury effectively undermined morally odious governmental compromises such as those embodied in the Fugitive Slave Laws. With such history in the background, the coalition of populists, liberals and libertarians who employed the Warren Court in support of progressive causes understandably saw in the jury a shield against governmental abuse of power. The decisions of the warren Court are thus replete with glowing language with which the Court expanded the role of both the civil and criminal juries. The expansion has been justified in terms of the jury as the "bulwark" of our democratic system; and this stance continues even though in the most recent past, high-profile jury verdicts (which, more often than not, implicate race) may be just as likely to be indisputably antithetical to the preferences of the majority of the population as to support it. Moreover, a close scrutiny of history will yield as many - and more likely, more - high-profile cases in which the jury decisions appeared to bend to the will of the powers that be as in opposition to it. And, of course, the vast majority of cases, even in the most liberal of democratic republics, have little to do with highly charged political issues. The ordinary trial, whether criminal or civil, involves little more than the state acting as an arbiter between one who claims wrongful conduct, and another who pleads innocence. To be sure, if the state's role is to be accorded respect, the process by which it arbitrates the competing contentions of the parties (including itself, when it prosecutes), must be seen to be fair. An impartial jury may contribute to such a perception, but there is no obvious 
connection between impartiality and the democratic ideal. To idolize the jury system on the ground that it embodies democratic ideals is, therefore, not necessarily tantamount to a claim about its efficacy as a problem-solving device in a judicial system. That idolization may be justified, however, on one of two grounds: the historical and the symbolic. Let us now examine the symbolic.

\section{The Jury as a Democratic Institution}

Although it is now reflexive to apply the term "democratic" more in approbation than description, the modern jury system is commonly portrayed as sharing several of the attributes that the term has come to connote. But at first blush, the proposition is at least debatable.

The origins of the jury under Norman practice lay in the vouching by kinsfolk of the character of the defendant. Effectively assembling a jury thus constituted a vote of confidence in the continued membership of the defendant in the civil community from which he would otherwise be excommunicated, whether as a convict or a judgment debtor. The assembling of a jury today of course serves a quite different purpose. Among other distinctions, the members of the modern jury, although said to be "peers" of the person over whom they will sit in judgment, are expressly required to be thoroughly unacquainted with the defendant, and, as much as possible, to be unconnected with the events over which they would be sitting in judgment. And they are selected through a process that appears more reflective indifferent impartiality of a lottery draw than of the informed passion with which one associates political democracy. What then makes the modern jury a "democratic" institution? 
The justifications of the jury as a democratic institution proceed along two axes: the participatory and the representative, with both converging at the point of deliberation. With regard to the former, the jury process affords the citizen, it is said, an unparalleled opportunity to participate directly in the process of self-governance. In the courtroom and its precincts, an otherwise indifferent citizen is made to confront the responsibility of evaluating the conduct of her fellow citizen, familiarizing herself with the legal rules and norms of her society, gauging governmental conduct, and ultimately calling the parties to account for their conduct. The individual juror is thus empowered, along with her colleagues, to sit in judgment both over fellow citizens, and most importantly, over her government and the institutions that the government uses to assert power and authority. And the jurors do so through the process of deliberation. Through these processes, law and society are rendered intelligible and accessible to the citizen juror who is thus empowered to take her participatory activism into other arenas of political participation. This is the basic thesis of the several books that have looked at the jury from the vantage point of a participant in the jury room.

The other justification of the democratic underpinnings of the jury process is grounded on its purported "representative" character. The view here appears bottomed on a series of related assumptions. First, because the modern jury seeks to draw its membership from a cross-section of the political jurisdiction within which it sits, it is assumed that the members therefore represent the component population of the jurisdiction. Secondly, it is also assumed that justice in the particular case is to be favored when it is the product of the participation of a cross-section of the political community. Thirdly, given the diversity of views inherent in a cross-sectional pool of 
persons, the demand of unanimity in a jury verdict (or, at least qualified super-majority voting), and the equal weighting of votes, jury members necessarily engage in extended deliberation in order to arrive at a verdict. The jury here is said to be democratic, not because of the values absorbed or made use of by individual jurors, but because the will of the jury is equated to that of the community.

The composition of the jury and its verdict thus are taken as microcosms of the larger society. A representative jury thus empanelled may validly override a general rule by refusing to apply it in the particular case, if, in its view, justice is better served thereby. This is of course the process of "jury nullification.) Similarly, in deference to the representative character of a trial jury, an unelected judge ought not to disregard a jury verdict; at least, not unless there are exceptional circumstances for doing so. A similar deference is owed the decision of a grand jury regarding its decision to indict. And finally, the same concerns that motivate the insistence on the secret ballot as a safeguard of popular democratic political practice are advanced to support the secrecy in which jury room deliberations and the votes of jury members are often clothe and justified.

The significance of the participatory justification for linking jury practice with democratic values can be dispensed with quite easily. Even if one completely credits the civic virtues that supposedly are embedded in the participation of the individual in the jury process, it does not follow that the maintenance of a democratic political order is inexorably linked to the jury process, nor that the validity and efficacy of the jury system depends on the maintenance of a democratic order. Participation in the jury system may well foster a democratically-inclined citizenry, but so also, one assumes, can other 
institutions; and these latter may well be both more effective and more efficient in delivering the good. The educational system, for example, can be targeted with greater precision than the jury to obtain some of the claimed-for results. More specifically to the point, it seems correct to say that as long as the focus of the participatory system is on the benefit conferred on the individual juror (even if society benefits derivatively thereby), there remains an unbridgeable gap between the acknowledged function of the jury as an arbiter of adjudicatory interests, whether between private parties, or between a private person and the state. The function of the jury is not to create a model democratic citizen, but to adjudicate conflicting claims to socio-economic goods; at least as long as those claims are presented in adjudicable terms.

The relevance a democratic order of the representative character of a jury, and its implication as a source of the legitimation of jury decisions deserves more serious attention. Appropriate scrutiny demands confronting at least two sets of issues. First, is there empirical support for the claim; and secondly, what are its normative implications? I address these issues in the next section.

\section{The Representative Jury and Democratic Values}

Since at least 1975, the United States Supreme court has insisted that a properly constituted jury must be fairly representative of the cross-section of the political jurisdiction from which its members are drawn. Relatedly, it has struck down on constitutional grounds the naked use of the peremptory challenge to remove on race or sex-based grounds otherwise qualified jurors. Members of the jury pool are thus drawn essentially from the same basic demographic and political constituency as the voters. Indeed, it is standard fare to identify as the irreducibly exclusive identifier of citizenship 
the right or privilege to vote and to be a juror. This of course does not mean that all potential jurors have equal chance to sit in the jury box any more than equal citizenship implies an equally realistic chance for every citizen's vote to have the same weight in deciding the presidency of the United States. Membership within a subgroup of the community - as a lawyer, school teacher, stay-at-home mother, Lesbian, Lutheran, Smoker, professed opponent of the death penalty, or wearer of eyeglasses -- to list a few examples - continue to weigh in the balance on whether an individual is admitted to membership on a particular jury. But these highly particularistic deviations do not undermine the representative credentials of the modern jury. The reality is that political democracy has never fully embodied - at least, to the extent that representation by individuals can - all possible communal interests. But there is no doubt that representation on the modern jury has grown along with expansion of the electoral franchise, and that today’s jury represents a much broader span of views and interests than did its eighteenth century counterpart that, after all, was based on property ownership and gender.

But granting the demographic representativeness of the modern jury is not tantamount to affirming the democratization of the ideologies that underpin it. Indeed, given the vast sums of money spent on the jury selection process, there is reason to ask whether a seated jury pool is in fact a democratic representation of the community from which it is drawn. Anecdotal evidence in high-profile cases similarly support skepticism of the extent to which the views and considerations that shape jury verdicts are in fact coextensive with those of the wider population. But an effective answer to the question would require delving into statistical evidence which is beyond the capacity of this paper 
to furnish. Let us therefore concede the point, and assume that demographic and ideological representativeness go hand-in-hand; and the views of the jury in fact mirror those of the political community. But this concession raises a further question: is the disposition of a judicial case by a representative jury that fairly mirrors the democratic composition of a society a normative good? The answer to the question, I think, requires comparing the social values at stake in the adjudication of cases and the democratic structures of a society. Here, I focus on the basics of both.

At core, democracy is about effectuating the self-governance of a society. Much as we prize the autonomous capacity of the individual to decide between good and bad, a proponent of democracy believes that the best choice for a society comes from the aggregation of autonomous preferences, not necessarily their fusion. Direct consensual participation by every member of the society would be optimal, but in its absence representation and majority rule are second order preferences. Contemporary democratic institutions and structures have, as their primary function, bridging the gap between the ideal of direct consensual participation and the reality of its impossibility. The demand for accountability that is often posited as the essence of democratic governance would not be necessary but for this disjuncture between the ideal and the real. Does and should the jury system qualify as one such institution?

All cases, at core, are about preserving social peace. Nonetheless, it may be helpful here to distinguish between those cases that arise because of conduct that directly threatened the security of the society as a whole (imprecisely, we may think of these as “criminal” cases), and cases in which one member of society asserts a claim against another. Here, the effect of adjudication on the maintenance of social peace is indirect. 
Because the former case ostensibly represents a threat to self-governance, a representative jury may well stand in for what would otherwise be the right of each and every member to sit in judgment over the threat. This argument would be especially strong if we view punishment as a decision of whether or not to excommunicate the miscreant from membership within the political community. On the other hand, might it not be precisely in his situation that a representative jury is most dangerous? If the representative jury is no more than the aggregation of the self-interests of those whom they represent, this would indeed be a major concern. The proponents of juries as democratic representatives claim, however, that the process of deliberation permits jurors to take account of not only the immediate self-interests of their constituencies, but the longer run interests of the community as a collective institution.

The arguments for a representative jury when confronted with a criminal case would seem to be inapposite in a non-criminal case. Here, it is difficult to see what is self-expressive or self-determining when one sits in judgment over conflicting claims by two other individuals. The detachment exists even where the claims arguably are sociologically representative; for, it is in the nature of litigation that individuals rarely project themselves into the position of one who suffers the misfortune of being a participant. And, to the extent that there are representative societal interests to be vindicated in a non-criminal lawsuit, the legislative enactment of the substantive and procedural rules that frame the lawsuit are probably sufficient to satisfy them. It is in such a lawsuit that the need for a genuinely dispassionate decision-maker would seem most apt. 


\section{A Last Discordant Note}

Thus far, I have operated on the assumption that democracy and democratic values are unalloyed goods. There is at least one sense in which this assumption is wrong. Even in their most idealized conceptions, democratic institutions are indifferent to the welfare of persons who do not belong to the political community. Since democratic theory posits the operation of democratic institutions within limited territorial boundaries that constitute the political community - village, town, county, state, country - the practice of democracy ineluctably suffers from a human rights deficit. What consideration does a democratic polity owe outsiders who are temporarily in its midst? A representative jury, if it is genuinely a democratic institution cannot avoid the dilemma that while its democratic credentials require it to be indifferent, the administration of justice, if viewed as a human right, requires it to step outside the democracy cocoon. That, of course, is an issue squarely presented by recent controversies over such legislation as the Detainees’ Treatment act and the Military commissions Act. 